\title{
Bağımlı Kişilik Örüntüsü ve Terapötik İşbirliği: Şema \\ Odaklı Bilişsel Davranışçı Terapi Uygulaması
}

\author{
Uzm. Psk. Duygu Yakın \\ Orta Doğu Teknik Üniversitesi, Psikoloji Bölümü
}

\begin{abstract}
Özet
Bağımlı kişilik örüntüsü (BKÖ) klinikte tedavi gören danışan örnekleminde oldukça yaygındır. BKÖ gösteren kişilerde diğerlerine aşırı güvenme, yetersizlik hisleri, zedelenmiş özerklik ve yapışkan davranışlar görülebilir. Hali hazırda sağlanan bakımı sürdürebilmek için duygusal açıdan bakım veren kişilere yönelik itaat davranışları görülebilir. Öte yandan, bu kişiler temel ilişkilerini tehlikede hissettiklerinde oldukça girişken ve iddialı davranışlarda da bulunabilirler. Kişilik bozuklukları perspektifinden bakıldığında da, C grubu bozukluklar genellikle psikoterapiye daha iyi cevap verirler. $\mathrm{Bu}$ grubun içerisinde de bağımlı kişilik bozukluğuyla yürütülen çalışmalar daha iyi tedavi sonuçlarına işaret etmektedirler. Ancak, farklı tedavi yaklaşımlarının bağımlı kişilik bozukluğunu tedavi etmedeki etkililiklerine yönelik araştırmalar kısıtlıdır. Bu çerçevede, bağımlı kişilik bozukluğu veya örüntüsüne sahip kişilerin tedavisinde hangi spesifik tekniklerin etkili olduğunun araştırılması önem kazanmaktadır. BKÖ’ne yönelik şema terapi modelleri, şemalarla ilişkili bilişler ve şema modları çerçevesinde,terapötik ilişkiyi ele almanın terapi sürecinde temel amaç oluğunu vurgulamaktadır. $\mathrm{Bu}$ yüzden mevcut vaka analizinde, bağımlılı̆̆ın spesifik yönlerinin ve terapötik ilişkide bu yönlerin nasıl kendisini gösterdiğinin klinik deneyim ve mevcut yazın çerçevesinde incelenmesi amaçlanmıştır. Yazından elde edilen bilgiler, daha kapsamlı bir içerik sunabilmek için bağımlı kişilik bozukluğu tanısı alan 43 yaşındaki bir kadın danışan üzerinden tartışılmıştır.
\end{abstract}

Anahtar kelimeler: Bağımlı kişilik örüntüsü, terapötik ittifak, şema odaklı bilişsel terapi 


\title{
Bağımlı Kişilik Örüntüsü ve Terapötik İşbirliği: Şema Odaklı Bilişsel Davranış̧ı Terapi Uygulaması
}

\begin{abstract}
Bağımlılık; cinsiyet, kültür ve etnik kökenden bağımsız olarak her insan tarafından paylaşılan evrensel bir deneyimdir ve çocukluk yaşantılarının yanı sıra, yetişkinlik döneminde de insan ilişkilerinde önemli bir rol oynamaya devam etmektedir (Bornstein, 1992). Ancak, bağımlılık aşırı düzeye ulaştığında, patolojik hale gelir ve işlevsellikte bozulma ve kişilerarası ilişkilerde sorunlara sebep olabilir. Bu açıdan, aşırı bağımlılık ve itaatkar davranışlar BKÖ ile ilişkilendirilmektedir (Beck, Freeman, ve Davis, 2003; Sperry, 2003).

Tanısal açıdan bakıldığında, DSM-IV- TR' ye göre bağımlı kişilik bozukluğu (BKB), kişinin hayatına yoğun stres getiren ve işlevselliğini bozan, itaatkar ve yapışkan davranış örüntüsüyle sonuçlanan yoğun bakım ihtiyacı ve ayrılma kaygısına karşılık gelmektedir (American Psychiatric Association, 2000). BKB kaçıngan ve obsesif-kompulsif kişilik bozukluğu ile birlikte kaygılı ve korkulu grup olarak belirlenen $\mathrm{C}$ grubu kişilik bozuklukları dahilindedir. Seligman ve Reichenberg'e göre (2007) BKB' nin sıklığı kişilik bozukluğu örnekleminde \%14, normal örneklemde ise \% 2, 5 civarındadır (aktaran, Faith, 2009). Borstein (2004) ilgili araştırmaları gözden geçirmiş ve bu çerçevede aşırı bağımlılığı eksen birde depresyon, kaygı, yeme bozukluğu ve somatizasyonla, eksen ikide ise sınır kişilik bozukluğu, histriyonik ve kaçıngan kişilik bozukluluklarına yönelik riskle ilişkilendirilmiştir. BKB' nin kadınlarda daha sıklıkla görüldügü düşünülse de, bu bulgu sadece öz-bildirim ölçeği kullanan araştırmalarda geçerlidir. Projektif ölçek araştırmalarında cinsiyet farklılığı gözlenmemektedir. Buradan hareketle, öz-bildirim ölçeği araştırmalarında gözlenen farklılık kültürün desteklediği toplumsal beklentilere atfedilmektedir (Bornstein, 1992; Sperry, 2003).

Bağımlı kişiler doğru karar verme yetisinden yoksun olduklarına inanırlar. Bu yüzden, yetişkin hayatının gereklerini yerine getirebilmek için güçlü birine güvenme ihtiyacı içerisindedirler ve bu kişinin yanlış davrandığını düşünseler dahi, reddedilme veya terk edilmenin yaratacağ 1 yoğun kaygıdan kaçınmak için tam bir itaat içerisinde bulunurlar. Genellikle özgüven problemleri vardır ve kendilerini başarı ve becerileri için takdir etme yetisinden yoksundurlar (Arntz, 2012; Beck, Freeman, ve Davis, 2003). Öte yandan, BKB' nin DSM-IV TR'de belirtilen tanısal ölçütleri büyük ölçüde eleştirilmektedir. Arntz'a (2012) göre bu ölçütler, hem duygusal hem de işlevsel bağımlılığa yönelik belirtileri içermektedir. Oysaki, bu iki tür bağımlılığın kökenleri arasında belirgin farklılıklar bulunmaktadır. BKB'ye sahip kişiler daha az işlevsel bozulma gösterdiklerinden, sayıları normal örneklemde oldukça fazladır (Faith, 2009; Sperry, 2003). Bu yüzden, Skodol ve arkadaşlarına göre (2011), DSM-V' in kişilik ve kişilik bozuklukları çalışma grubu, BKB' nin gelecek basımlarda tanısal kategori olmaktan çıkarılmasını ve kaygı, itaatkarlık ve ayrılma kaygısı ekseninde yeniden tanımlanmasını uygun görmüştür (aktaran, Bornstein, 2012). Bu yüzden bireyin kişiliğini bağımlı olarak tanımlamak yerine bağımlı davranışları belirleyip etiketlemek daha uygun görülmektedir (Mitchell, 2008). Mevcut vaka analizinde de, çalışılacak sorunlar kaygı, itaatkar davranışlar ve ayrılma kaygısı ekseninde kavramsallaştırılmış ve tedavi planı bu özelliklere ilişkin mod çalışması ve imajinasyon gibi tekniklerin kullanımını içerecek şekilde oluşturulmuştur. Bu yüzden, BKB’nin tanısal ölçütlerine
\end{abstract}


yönelik eleştiriler göz önünde bulundurularak, mevcut vakanın da BKB'den ziyade BKÖ profili kapsamında değerlendirilmesi uygun görülmüştür.

Borstein (1992, 1993, 2011), bağımlılığın gelişimini farklı teorik modeller açısından incelemiş ve ebeveyn-çocuk ilişkisinin bağımlılığın gelişiminde en önemli belirleyici olduğunu belirtmiştir. Buna göre otoriter ve katı bir şekilde aşırı koruyucu ebeveynlik, bağımlılık düzeyindeki artışla ilişkili bulunmuştur. Bu durumun çocuğun öz-yeterlik hissini etkileyeceği, bağımsız davranışın cezalandırılması ve bağımlılığın pekiştirilmesi sonucu çocuğun özerklik kazanmasının engelleneceği ve çocukların kendilerini işe yaramaz ve yetersiz olarak değerlendirmeyi öğrenecekleri vurgulanmıştır (Arntz, 2012; Bornstein, 2011). Yanı sıra, çocukluktaki duygusal istismar da yetişkinlikteki bağımlılıkla ilişkilendirilmektedir. Ebeveynlerinin en iyisini bildiğini düşünen çocuklar, yetişkin hayatlarında da kendilerine neyin doğru olduğunu söyleyecek güçlü birisine ihtiyaç duyma riski altındadır (Arntz, 2012).

BKB' nin tedavisine yönelik nitelikli araştırmalar kısıtlı olsa da, olumlu sonuçlar belirten farklı tedavi yaklaşımları bulunmaktadır. Diğer kişilik bozukluklarına göre BKB tedavisinin daha kısa sürdüğü ve daha sorunsuz geçtiği belirtilmektedir (Sperry, 2003). Kişilik bozukluklarının tedavisinde pratik ve etkili bir yöntem olarak bilinen bilişsel davranışçı tedavi yaklaşımı, bağımlı kişilik özelliklerinin tedavisinde makul ölçüde ilerleme sağlamakta ve farklı belirti gruplarına yönelik bütünleşik tedavi paketleri sunmaktadır (Beck, Freeman,ve Davis, 2003; Bornstein, 2004; Matusiewicz, Hopwood, Banducci veLejuez, 2010). Bunların arasında şema terapi, kişilik bozukluklarında görülen katı özelliklerden kaynaklı uzun süreli sorunların tedavisine yönelik alternatif sunmaktadır ve uzun süreli sorunlar için daha kapsamlı bir kavramsallaştırma ve tedavi planı oluşturabilmek amacıyla erken dönem olumsuz şemalarla çalışmayı önermektedir (Sperry, 2003; Young, Klosko ve Weishaar, 2003; Rafaeli, Bernstein ve Young, 2011).

Son dönemde, kişilik problemleriyle çalışan terapistler şemalar yerine şema modlarıyla çalışmanın daha etkili olduğunu belirtmektedirler. Kişinin hayatı boyunca görece daha istikrarlı olan şemaların aksine, modlar belirli bir zaman içerisinde ağır basan duygusal durum, şema ve başa çıkma tepkilerinin bütününü ifade etmektedir (Rafaeli, Bernstein ve Young, 2011). Bağımlı kişilik ekseninde şema terapi süreci, çoğunlukla söz dinleyen teslimci mod üzerine yoğunlaşmaktadır. Bu mod kişinin çaresizlik hislerinden kaynaklı olarak kendisinden güçlü algıladığı bireylere karşı itaatkar davranışlarını içermektedir. Bu modda, mevcut ilişkiyi korumak ve terk edilmekten kaçınmak amacıyla, birey otorite figürlerinin talep ettiği her şeye uyum göstermekte ve tam bir teslim sergilemektedir(Arntz, 2012; Young, Klosko ve Weishaar, 2003). Çocuk modlarından, bağımlı çocuk modu aktif olduğunda, kişi kendisine hayatın getirdiği sorularla ilişkili pratik çözümler sunacak güçlü bir yardımcının yokluğunda paniklemektedir. Benzer şekilde, terk edilmiş/ istismar edilmiş çocuk modu da genellikle duygusal istismar yaşantılarından kaynaklı reddedilme ve terk edilme korkularıyla ilişkilendirilmektedir. Son olarak, hataları için kişileri sürekli rahatsız eden içselleştirilmiş cezalandırıcı ve eleştirel ebeveyn modlarının varlığı gözlenmiştir. Sağlıklı yetişkin modunun ise zayıf olması beklenmektedir (Artnz, 2012; Bamelis ve ark., 2011). Şema terapi uygulanırken şemaların varlığı ve modların isimlendirilmesi kişinin şema ölçeklerinden aldığı puanlamalara göre yapılmaktadır.

Bağımlı kişilik danışanlarının diğer kişilik bozukluğu danışanlarına göre psikoterapi için daha uygun olduğu belirtilse de, bu alandaki çalışmalar oldukça kısıtlıdır (Faith, 2009). Bu yüzden, mevcut çalışmanın amacı bağımlı kişilikte şema terapinin kullanılmasına yönelik klinik veri sağlamak ve vaka örneği olarak Bayan B.'nin çocuk modlarına giden yolda buzdağının görünen yüzü olan ilişkisel problemleri tanımlamaktır.

Bayan B., 43 yaşındadır ve bir şirkette çalışmaktadır. İyi bir kariyeri vardır ve pek çok iş teklifi almaktadır. Kliniğimize, ilişki problemleri yüzünden yaşadığg depresif belirtilerin 
endişelendirdiği eşi tarafından yönlendirilmiştir. Beş yıldır evli olduğu eşiyle uzun süredir iletişim problemleri yaşadığını ve görüşmeye gelmeden 2 yıl önce başlayan bir evlilik dışı ilişkisinin olduğunu ifade etmiştir. İlk görüşmeler süresince oldukça gergin gözüken Bayan B.'nin kolaylıkla duygusallaştığı ve sık sık ağladığı gözlenmiştir. Bayan B.'nin kendisini hiçbir işi beceremeyen biri olarak gördüğü ve eşi tarafindan yalnız bırakılmaktan korktuğu öğrenilmiştir. Eşi hakkındaki düşüncelerini “Onsuz ben ne yaparım? Bana kim bakar? O olmadan terapiye bile gelemem!” şeklinde özetlemiştir. Öte yandan, eşiyle cinsel problemlerinin olduğunu, eşinin politik görüşlerinden hoşlanmadığını ve artık eşini sevmediğini de eklemiştir. Evliliği ailesinin yoğun 1srarları yüzünden gerçekleştiğinden, aslında eşini daha önce sevip sevmediğini de değerlendiremediğini ifade etmiştir. Çocukluktan beri sık sık böyle depresif hissettiği dönemler olduğunu da eklemiştir.

Bayan B.'nin annesi neyin nasıl yapılması gerektiğine yönelik katı kuralları olan duygusal açıdan donuk, kuralcı bir kadındır. Bayan B.'nin işleri tek başına yürütebilecek kadar yeterli olmadığını düşündüğünden, genellikle deneme yanılma yoluyla öğrenmesine firsat tanımamış, her şeyi onun için hazır etmiş ve en ufak hatada da onu cezalandırmıştır. Bayan B.'nin babası çocuklarının başarılarıyla yakından ilgilenen hırslı ve çalışkan bir adamdır. $O$ da duygularını göstermekten hoşlanmadığı için stresle ilişkili somatik rahatsızlıklardan yakınmaktadır. Bayan B.'nin ebeveynlerinin mesajların dolaylı olarak iletilmesini içeren psikolojik kontrol mekanizması kullandığı izlenimi edinilmiştir. Bu, depresyon ve kaygı belirtilerinde artışla ilişkilendirilmektedir (Soenens, 2007). Böylelikle, cezalandırıcı ve eleştirel ebeveyn modlarının içselleştirilmiş ebeveyn figürlerinin varlığıyla açıklanabileceği düşünülmüştür. Özetle, ailede duyguların ifadesi katı bir şekilde cezalandırılırken Bayan B.’nin kendisine yönelik negatif düşünceleri desteklenmiştir.

Bayan B., kendisini hep bakıma muhtaç, yetersiz biri olarak gördüğünü belirtmiştir. Ergenliğinden beri her zaman ona göz kulak olacak birilerinin olduğunu ve ne zaman reddedilmeye yönelik bir işaret algılasa, başka bir ilişkiye yöneldiğini ve önceki ilişkisinin de bu aldatma sonucu bittiğini ifade etmiştir. Ayrılık tehlike arz ettiğinden, ilişkisi bittiğinde güvenecek yeni insanlar arama eğilimindedir. Bayan B.'nin gerçek ya da hayali bir terk edilmeden kaçınmak için istismar edici ilişkilerinde dahi itaatkar davrandığı gözlenmiştir. Kendisini ifade edemediğinde kusma, baş ağrısı, burun kanaması gibi bedensel belirtiler gösterdiğini belirtmiştir.

\section{Terapötik İlişki ve Şema Terapi}

Son yıllarda yapılan çalışmalar terapötik ittifakın özellikle terapinin erken dönemlerinde ilerleme kaydedebilmek için önemli kavramlardan biri olduğu konusunda hemfikirdir (Diener ve Monroe, 2011; Lingiardi, Filippucci ve Baiocco, 2005; Martin, Garske ve Davis, 2000; Rector, Zuroffve Segal, 1999; Strauss ve ark., 2006). Terapötik ittifak kavramı, psikoanalizin erken dönem kavramlarından biri olsa da, pek çok araştırmacı farklı teorik çerçevelerden ittifakın önemine değinmiştir. Bunlar arasında, Bordin (1979) terapötik ittifak kavramını ilk kez bütün psikoterapi yaklaşımlarına genellenebilecek şekilde yeniden kavramsallaştırmıştır. Buna göre terapist ve danışan terapideki görevler, terapinin amaçları, ve terapist ile danışan arasındaki karşılıklı güveni yansıtan duygulanımsal bağ konusunda hemfikir olmalıdırlar. Bu özelliklerin bilişsel terapiyi de içeren pek çok terapi yaklaşımına genellenebileceği öngörülmüştür. Bilişsel terapi yazınını gözden geçiren çalışmalar, değişim sürecinde terapötik ittifakın herhangi bir teknik bileşen kullanımından çok daha etkili olduğu konusunda uzlaşmaktadır. Lambert ve arkadaşları (1986) terapötik ilerlemedeki varyansın \%45'inin ilişkisel faktörler tarafından açıklandığını öne sürmektedir. (aktaran, Rector, Zuroff ve Segal, 1999). Yanı sıra, iyi bir terapötik ilişkinin uygulanan teknik 
bileşenin etkisini de arttıracağı belirtilmiştir. Bu çerçevede, terapötik ittifakın güçlü kurulduğu bir ilişkinin bilişsel yeniden yapılandırma üzerinde olumlu etkileri olacağı ve çocukluktan kalan cezalandırıcı içselleştirilmiş figürlerin etkisinin terapistle kurulan sağlıklı bağlanma sonucunda azalacağı ifade edilmektedir (Rector, Zuroff ve Segal, 1999; Strauss ve ark., 2006). Öte yandan, bu kadar kapsayıcı bir kavram fikri ampirik çalışmalarla ilişkili olmayan yaklaşımların dahi dikkatini çekmiştir (Safran ve Muran, 2006). Böylelikle, bu alandaki araştırmalarda yoğun bir artış meydana gelmiş ve kavram farmakolojik yaklaşımda dahi "farmakoterapik ittifak" olarak yerini almıştır (Bender, 2005). Bu çerçevede, Safran ve Muran (2006), bu kavramın çağdaş araştırmacılar tarafından aşırı kullanımına dikkat çekmekte ve aşırı büyütülmesi konusunda uyarmaktadır. Buna göre, ampirik çalışmalarla yeni ölçüm araçları geliştirmek yerine, terapötik ilişkinin değişim sürecindeki yerini belirlemenin asıl amaç olması gerektiğini savunmaktadırlar ki, bu da mevcut vaka analizinin ana hedeflerindendir.

Öte yandan eğer terapötik süreçte kaçınılmaz bir şekilde meydana gelen bozulmalar görüşme içerisinde etkili bir şekilde ele alınmazsa, bu durum erken sonlanmalara neden olabilir. $\mathrm{Bu}$ yüzden terapötik ittifakta meydana gelen bozulmayı ele almak önem kazanmaktadır (Bender, 2005; Soygüt, 2004; Strauss ve ark., 2006). Bu durum Shafran ve Muran (2006) tarafindan ittifakta bozulma olarak adlandırılmış ve küçükten büyüğe uzanan bir boyut üzerinde tanımlanmıştır. Baillargeon ve arkadaşları (2012) bu konudaki yazını gözden geçirmiş ve bozulmanın uygun şekilde ele alındığında mevcut ilişkiyi güçlendirebileceği sonucuna varmışlardır. Bozulmanın varlığı doğası gereği bozulabilecek bir ittifakın var olduğuna işaret ettiğinden, ittifakta bozulma yaşanan terapilerin daha olumlu sonuçlanması beklenmektedir.

Danışanlarla açık ve empatik bir ilişki kurabilmek hem bilişsel terapinin hem de şema terapisinin temel amaçlarından biridir (Vreesewijk, Broersen ve Spinhoven, 2012). Şema terapide, terapi ilişkisi değişim sürecinde önemli bir unsur olarak kabul edilmektedir ve terapötik ilişkinin kendisi bir terapi tekniği olarak kullanılmaktadır. Shafran ve Muran (2006)'nın görüşleriyle paralel olarak, şema terapide de terapistlerin şema tetikleyici olayların ipuçlarına dair hassasiyet göstermesi ve danışanlarla ilişkilerini ele alabilmeleri desteklenmektedir. Yanı sıra, şemanın tetiklenmesi kaçınılması gereken bir durum olarak belirtilmemekte, hatta şemalar tetiklendiğinde bu durumun terapist tarafından da körüklenmesi ve terapötik ilişkide bu durumun ele alınması önerilmektedir. Bu şekilde şema bağlantılı döngülerin belirlenmesi için terapi ilişkisinin güvenli yer olarak kullanılması ve terapistin“şimdi ve burada"ya odaklanarak ittifakta bozulmayı ele alması desteklenmektedir. Böylelikle, terapist mevcut ilişki deneyimleriyle, bunlara etki eden çocukluk yaşantıları arasında köprü kurmayı amaçlar (Rafaeli, Bernstein veYoung, 2011; Young, 1994).

Şema terapide terapötik ilişki kavramı iki önemli teknik üzerine kuruludur. Bunlar empatik yüzleştirme ve sınırlı yeniden ebeveynliktir. Şema terapinin ana odağı insanlara çocuklukta karşılanmamış ihtiyaçlarıyla baş etme konusunda yardımcı olmaktır. Bu yüzden, uygun sınırlar içerisinde danışana bu ihtiyaçları sağlamayı hedefleyen sınırlı yeniden ebeveynlik kavramı en önemli tekniklerden biridir. Terapötik ilişki danışan için güvenli yer olmasının yanında, değişimin öneminin de vurgulandığı ve danışanın gerçekliği objektif bir şekilde değerlendirdiği bir ortam olmalıdır. Bu yüzden empatik yüzleştirme şema davranışlarını devam ettiren örüntülerin, bunların sebeplerine yönelik empatik bir anlayışla danışana gösterilmesini hedefler. Buradaki temel amaç hem şefkatli, hem de objektif olabilen, samimi ancak oldukça açık bir üsluba sahip olmaktır (Young, Klosko ve Weishaar, 2003).

\section{BKÖ’nün Şema Odaklı Bilişsel Terapi Uygulamasında Terapötik İlişki}

Diğer kişilik bozukluğu gruplarına göre, $\mathrm{C}$ grubu hastaları, daha az problemli, daha kolay 
tedavi edilebilir ve ilişki kurması daha kolay danışanlar olarak kabul edilirler. Ancak, ilişki kurmak bu danışanlarla da oldukça zorlayıcı olabilmektedir (Arntz, 2012; Lingiardi, Filippucci ve Baiocco, 2005; Vreeswijk, Broersen ve Spinhove, 2012). Kişilik örüntüsüyle ilişkili problemler söz konusu olduğunda, ittifakta bozulma çok daha güçlü hissedildiğinden, bu bozulmanın ele alınması önem kazanmaktadır (Mitchell, 2008). Süregelen klinik görüşün aksine, Borstein (2012) bağımlılığın pek çok terapistin algıladığından çok daha karmaşık bir kavram olduğunu ve bu danışanlarla daha etkili çalışabilmek için terapistlerin bağımlılığın bütün yönlerini kapsayan hatasız ve incelikli bir bakış açısının olması gerektiğini savunmaktadır.

Bağımlı danışanların teslimiyetçi özellikleri terapinin başlangıcında ittifakı kurmayı kolaylaştırmaktadır. Teslimiyetçi özellikler danışanların içsel deneyimleriyle ilişkili olarak kendilerini tanımlamalarını zorlaştırsa da, bu kişiler teslimiyetçiliği bakım görmenin bir yolu olarak değerlendirmektedirler (Bender, 2005). Terapi ilişkisinde de bu tarz davranışlar terapist hasta etkileşiminin görece daha az olduğu klasik psikanalizdense, ilişkiselliğin ve iletişimin yoğun olduğu içgörü odaklı terapilerde görülmektedir (Bornstein ve Bowen, 1995).

Hatırı sayılır bir çoğunluk, kişilik bozukluklarıyla çalışırken yaşanan güçlüklere işaret etmektedir. Bu anlamda, bilişsel terapinin aşil topuğu, ittifakta bozulmaları ele almaya yeteri kadar önem göstermeyişi olarak kabul edilmektedir. Bu yüzden, bilişsel terapinin içerisinden görüşme sırasında terapötik ilişkinin ele alınmasını kapsayan yeni teoriler gelişmiştir (Soygüt, 1999).

Bağımlı kişiliğin karmaşık yapısı göz önünde bulundurulduğunda, bütünleşik yaklaşımların klinik uygulamada daha etkili olacağı belirtilmektedir (Bornstein ve Bowen, 1995; Bornstein, 2004). Buradan hareketle, şema terapi terapötik ittifakın da bir teknik olarak kullanıldığı bütünleşik bir yaklaşım olarak değerlendirilmiştir.

Daha spesifik olarak, şema terapininin bakış açısından bakıldığında bağımlı kişilik örüntüsüne yönelik modelinde, daha önce bahsedildiği gibi, söz dinleyen teslimci mod, bağımlı çocuk mod, terk edilmiş/ istismar edilmiş çocuk mod, cezalandırıcı ve eleştirel ebeveyn modunun gözlenmesi ve çalışılması gereken olası modlar olduğu bilinmektedir. Buna paralel olarak Bayan B. 'ye uygulanan değerlendirme yöntemleri sonucunda Bayan B.'nin yüksek puan aldığı şemalar sırasıyla iç içe geçme/bağımlılık, cezalandırılma ve onay arayıcılık şemalarıdır. Bununla birlikte terk edilme ve duyguları bastırma şemalarında da yüksek puan verilen maddeler bulunmaktadır. Buradan hareketle, Bayan B.'nin, terk edilmiş/ istismar edilmiş ve bağımlı çocuk modları ve bunlarla baş etmek için geliştirdiği bir söz dinleyen teslimci modu olduğu düşünülmüştür. Bayan B.'nin kendisini oldukça bağımlı ve muhtaç algıladığı, otorite figürlerince istenir davranışları uyguluyor oluşu, bu gereklilikleri yerine getirme konusunda başarısız olduğunda kendisine yönelik ağır eleştiriler yapıyor olmasıyla birlikte düşünüldüğünde, değerlendirme sonuçlarının klinik gözlemle ve mevcut yazınla tutarlı olduğu izlenimi edinilmiştir.

Tedavi sürecinde de, sınırlı yeniden ebeveynlik şema terapide yapılan pek çok müdahaleye temel oluşturan bir ilişkisel teknik olarak kabul edilmektedir (Rafaeli, Bernstein, Young, 2011). Bu yüzden terapinin başından itibaren terapötik ittifaka yönelik ipuçlarına dikkat edilmesinin önemine değinilmektedir. Daha önce de belirtildiği gibi, genellikle bağımlı danışanlarla ittifaka yönelik ilk izlenim olumludur. Bayan B.'nin de ilk birkaç seans süresince oldukça özenli davrandığı ve tedavi sürecine oldukça yatırım yaptığı izlenimi edinilmiştir. Seans için programlarını iptal ettiğini ya da tatilini erken kestiğini belirten Bayan B.'nin, terapistinin hemen her yorumunu onayladığı ve sıklıkla terapistin becerilerini övdüğü gözlenmiştir.

Terapötik ittifak terapi sürecinin yordanması açısından kritik bir öneme sahip olsa da, erken dönemde kurulan terapötik ittifak, terapistin hastayı daha girişken bir rol alması için cesaretlendirmeye çalışmasıyla hızlıca zayıflayabilir. Danışanlar, değişmek için bağımsız olarak bir şeyler yapmaları gerektiğini farkına vardıklarında, tek başına bırakıldıklarını düşünebilir ve bununla ilişkili kaygı ve depresyon belirtileri sergileyebilirler (Beck, Freeman ve Davis, 2003). 
Bağımlı kişilik özelliklerine sahip danışanlar, sınırlı yeniden ebeveynlikte de değinilen yeterince iyi ebeveynden ziyade, kendileriyle ilgilenecek tüm güçlü birini ararlar. Bu yüzden karar verirken genellikle terapistlerin fikrini öğrenme konusunda 1srarcıdırlar ve verdikleri kararlara yönelik de geribildirim beklerler. Bu verilerle tutarlı olarak, Bayan B. davranışlarına yönelik terapistinden sürekli geribildirim beklediği, ne yapması gerektiği konusunda kendisini yönlendirmesini istediği ve terapistin yönlendirici olmayan davranışlarını zorlayıcı bulduğu gözlenmiştir. Bayan B. "Terapistlere artık danışanlarına ne yapacaklarını söyleme hakkı verilmeli" diyerek bu tavrı şakayla karışık eleştirmiş ve durumdan duyduğu rahatsızlığ dile getirmiştir. Terapistin yönlendirici davranmayıp tarafsız kalması bekleneceği üzere, danışanlarda engellenmişlik yaratabilir (Bornstein, 1993). Yanı sıra, bu kişiler görünürde terapistle işbirliği içerisindeyken, terapistin onaylamayacağından ve kendilerine yabancılaşabileceğinden korktuklarından pek çok kişisel bilgiyi saklayabilirler (Bender, 2005). Bayan B.'de, terapi sırasında ağlamak gibi hata olarak gördügü ufak davranışlarda dahi kendisini cezalandırmaktadır ve sonradan anlaşıldığı üzere, evlilik dışı ilişkisiyle ilgili yargılanacağını düşündüğü ayrıntıları terapistinden uzun süre gizlemiş̧tir.

Bağımlı danışanların olumsuz duyguların ifadesi söz dinleyen teslimci mod tarafından ketlendiğinden, bağımlı kişiler ebeveynlerinin davranışlarını eleştirmeyi oldukça zor bulurlar. Bunun yerine kendilerini mağdur konumuna koyup güçsüzleştirir ve düzeltici deneyimler yaşamak için çabalamaktansa, bu konuma hapsolurlar (Arntz, 2012). Buna paralel olarak Bayan B. özellikle terapinin başlarında, ebeveynleri hakkında konuşmak için isteksiz gözükmekte ve kusurlu olduğuna inandığı için "kendi başarısızlıklarından başkalarını sorumlu tutmanın” yersiz olduğunu belirtmekte, bu yüzden enerjisini daha üretici alanlara kullanmak yerine genellikle kendine acımaktadır. Overholser'ın (1997) benzer bir vakasında, bu durumda terapistin danışana mevcut başa çıkma şeklinin (şema terapi dahilinde şema devamının) altta yatan bağımlı ve zarar görebilir yapının değişiminde etkili olmadığını göstermesi desteklenmektedir. Böylelikle, güçlü bir figür olarak terapiste güveniyor olmanın da daha önce başarısız olduğunu deneyimlediği şemayı devam ettiren başa çıkma tarzıyla benzeştiğinin altı çizilmelidir (Young, Klosko ve Weishaar, 2003). Overholser'a (1997) göre terapistler, danışanlarının kendilerine acımayla ilişkili olumsuz hislerini azaltmak için sosyal destek sağlamaktansa, bu hislerin sağlıklı bir şekilde tolere edilmesi, mutlu ve güvende hissetmek için başkalarına değil, kendilerine güvenmenin öneminin anlaşılması üzerine çalışmalıdırlar.Bu yaklaşım, şema mod çalışmasındaki sağlıklı yetişkin modunun güçlendirilmesiyle paralellik göstermektedir. Bu anlamda, tedavi sürecinde Bayan B.'nin kaçınma ve telafi gibi işlevsel olmayan başa çıkma mekanizmaları, uyumlu çocuk, kırılgan çocuk ve eleştirel ebeveyn gibi farklı modlar çerçevesinde ele alınmış ve sağlıklı yetişkin modunun güçlenmesine yönelik rol oynama çalışmaları yapılmıştır.

Beck ve arkadaşlarına (2003) göre, siyah-beyaz düşünme bağımlı kişilik örüntüsüne sahip danışanlarının en önemli bilişsel çarpıtmalarından biridir. Bu kişiler, diğerlerini idealize etme ve kendi becerilerini küçümseme eğilimindedirler. Bu yüzden, ilişkileri kaybetmek tamamen felaketleştirilir. Bağımlı kişiler genellikle daha uyumlu stratejiler kullansalar da kendileri için önemli ilişkileri tehdit altında hissettiklerinde bu stratejileri çok daha girişken ve yıkıcı davranışlarla değiştirme riskleri vardır (Bornstein, 2012). Tahmin edilebileceği gibi, bu dinamik, terapi ilişkisi açısından oldukça önemlidir. Bağımlı danışanlar, kendilerini çoğunlukla tam bir başarısızlık abidesi olarak algıladıklarından, terapistin hastayı kurtarma dürtüsü altında ezilmemesi önemlidir. Bayan B.'nin terapi ve terapistin süpervizyon sürecinde de, bahsi geçen temalar oldukça belirgin şekilde gözlenmiştir. Seanslar ilerledikçe, terapist süpervizyon yardımıyla Bayan B.'ye diğer danışanlarına göre daha hassas ve özverili davrandığını ve Bayan B.'nin 'böylesi yetersiz bir danışan” olmanın ikincil kazançlarını yaşadığını fark etmiştir. Terapist bu süreçte kendini feda şemasının oldukça aktif hale geldiğini ve kendi karşı bağımlılık süreçleriyle 
desteklendiğini, danışanın sıklık ve süreyle ilişkili taleplerini karşılamak için yoğun bir çaba içerisinde olduğunu, bu çerçevede de kendi dinamiklerinin danışanı olduğundan daha kırılgan olarak değerlendirmesine sebep olduğunu süpervizörünün geribildirimleriyle fark etmiştir. Buradan da anlaşılacağı üzere, terapistlerin danışanlara karşı duygu ve davranışlarını kontrol edebilmesi için kendi şemalarının farkında olmaları gerekir. Dahası, danışanın özerklik kazanması zaman alacağından, terapist bu durumun yaratacağı engellenmişlik hissinden de kendisini korumalıdır (Beck, Freeman ve Davis, 2003).Bu anlamda terapistin şemaları da terapötik ittifakta bozulmaya yol açabilen önemli belirleyicilerdendir. Nord, Högert ve Eckert'in (2000) görüşlerine göre terapistlerin sadece \%20'sinin güvenli bağlanma stiline sahip olduğu düşünüldüğünde, terapistin şemalarının bağımlılıkla ilgili konularda sıkıntı yaratması olası gözükmektedir (aktaran,Soygüt, 2004). Örneğin danışanın bağımlılı̆̆ının aşırı olarak değerlendirilmesi terapistin yakınlıkla ilişkili sıkıntılarından kaynaklanabilir (Borstein veBowen, 1995). Benzer şekilde, Vane (2002) bağımlılıkla çalışırken terapistin örüntüleriyle ilişkili olabilecek konuları şema teorisi çerçevesinde ele almış ve terapistin kendi şemalarına yönelik iç görü kazanmasının duygusal materyali konuşmaktan kaçınmak ya da bağımlılıkla ilişkili materyalleri hatırlamakta zorlanmak gibi terapötik ittifakta kırılma yaratabilecek durumları önlediği sonucuna varmıştır. Önemli bir diğer bulgu da, terapistin kendi şemalarının ancak stres düzeyinin arttığı durumlarda hastanın şemalarıyla etkileşime girmesidir. Bu yüzden şema terapide süpervizyon desteklenmektedir (Young, Klosko ve Weishaar, 2003). Böylelikle terapistin tedavi sürecinde deneyimleyebileceği olası korku ve kaygının terapötik ilişki üzerindeki olumsuz etkilerinin safdışı bırakılabileceği düşünülmektedir. Bayan B. vakasında, süpervizyon yardımıyla terapist hem danışan (örn. bağımlılık/iç içe geçme çerçevesindeki talepler) hem de kendisi (örn. kendini feda şemasının etkisinde yapılan yeni düzenlemeler) için şema devamını sağlayan etkileşiminin farkına varmıştır. Böylelikle danışanın ikincil kazanç getiren davranışları da bağımlılık/iç içe geçme şemasıyla teslim olma şeklinde beş etme olarak kavramsallaştırılmış ve otonomiyi destekleyen sınırlar terapide belirginleşmeye başladıkça, terapist kaçınılmaz olarak Bayan B.' 'nin daha girişken tarafiyla tanışmak durumunda kalmıştır.

Bağımlı danışanlar immatür davranışlar gösterebilirler, engellenmeye karşı toleransları düşüktür ve bu davranışlar terapiyi erken sonlandırmalarına neden olabilir (Bornstein, 2012). Eleştiriye yönelik değerlendirmeleri kolaylıkla red olarak algilayabileceklerinden, terapistlerine karşı da oldukça şüpheci tutumlar sergileyebilirler (Bamelis ve ark., 2011). Alexander ve Abeles (1968) bağımlı kişilerin yetersizlik duyguları yüzünden aşırı talepkar olabileceğini ve terapist kaçınılmaz bir şekilde bu talepleri yerine getirmekte yetersiz kaldığında, terapötik ittifakta bozulmaların görülebileceğini belirtmişlerdir. Bu yüzden terapistlerin aşırı bağımlılığın işaretlerine yönelik tetikte olmaları desteklenmektedir. Bayan B.'nin terapistine kendisini daha yakın hissettiğini ifade ettiği ve daha önce gizlediği bir takım bilgileri paylaştığ bir görüşmeden sonra, terapistin yaptıklarını onaylamadığına işaret olabilecek fiziksel ve sözel ipuçlarına yönelik çok daha hassas duruma geldiği gözlenmiştir. Terapistin beden duruşundaki ufak değişiklikleri hızlıca yakalamakta ve terapistin hoşnutsuzluğu olarak yorumlayabilmektedir (Örn. dediğim şeyden hiç hoşlanmadınız, değil mi?). Bu süreçte Bayan B.'nin bir taraftan terapistin onayı için yoğun olarak çabaladığ 1 , bir taraftan da bağımlılıktan ileri gelen gereksinimlerinin terapinin doğası gereği tam olarak karşılanmıyor oluşundan duyduğu engellenmeyi kontrol etmeye çalıştığ izlenimi edinilmiştir. Mitchell (2008) bağımlı kişilik danışanlarının terapi sürecindeki davranışlarını gözden geçirdiği bir çalışmasında, bu kişilerin tedavi sürecinde gelgitler yaşayabileceği ve bağımsız davranışlar sergilemelerinin zaman alabileceğini belirtmiştir. Bu süreçte terapistler tatile çıkma ya da seanslara gecikme gibi "masum" geri çekilme davranışları sergilediklerinde, ittifakta çok daha şiddetli bozulmalar yaşanabileceğinin altı çizilmiştir. Çünkü bu tarz davranışlar danışan tarafından reddedilme ve terk edilme olarak algılanma riski yüksek davranışlardır ve erken sonlanmaya yol 
açabilirler (Bender, 2005). Bayan B.'nin durumunda, yakınlık hislerinin ifadesinden kısa bir süre sonra terapist sağlık durumu nedeniyle iki seansı üst üste iptal etmek durumunda kalmıştır.

Sonraki ilk görüşmede Bayan B. görüşmelerden kopmuş gözükmektedir ve terapisti geçen hafta dışarıda gördüğünü belirtir. Buna yönelik olası kırgınlığının ifadesi terk edilme ve reddedilme hisleri tarafindan engellenmiş gözükmektedir. Ancak Bayan B. bu duruma yönelik hislerini sağlıklı yetişkin modundan ifade etmektense, tepkisini soğuk bir ses tonuyla, sarkastik bir şekilde "Bu soğukta dışarı çıkarsanız hastalanırsınız tabi!"şeklinde belirtmiştir.

Şema terapide terapistin ittifakı sürdürebilmek için danışanlara ilişkiye yönelik olumsuz davranışların kısıtlanmasını, yıkıcı davranışların empatik bir şekilde yüzleştirilmesini ve danışana ilişki içerisinde terapistin düşüncelerine de karşı çıkmanın desteklenmesini içeren geribildirimler vermesi desteklenir (Vreeswijk ve ark., 2012). Görüşme sırasında tetiklenen şemaların ele alınması, şemaların günlük hayattaki etkililiğini azaltmanın bir yolu olarak görülmektedir. Böylelikle, terapist şemalarla ilşikili temel problemleri ele alır ve daha iyi başa çıkma yolları önerir. Bu anlamda, terapistin yokluğunda hastanın okuyabilmesi için başa çıkma kartlarının hazırlanması da önerilmektedir (Young, Klosko ve Weishaar, 2003). Bayan B.'nin terapisinde meydana gelen ittifaktaki kırılma, bağımlılık/iç içe geçme ve terk edilme şemaları çerçevesinde ele alınmış ve bu davranışın altında yatabilecek olası kırılgan duyguları ifade etmiyor olmanın olası avantaj ve dezavantajları başa çıkma kartı üzerinde tartışılmıştır. Sonrasında, yıkıcı davranış etiketlenmiş ve bağımlı çocuk moduna yönelik duyguların telafi yoluyla eleştirel/cezalandırıcı ebeveyn modu üzerinden ifade edilmesi şeklinde kavramsallaştırılmıştır. Bu süreçte, bir seans sırasında Bayan B. terapist tarafından terk edilmiş hissetmenin kendisini ne kadar üzdüğünü oldukça zorlanarak ifade etmiştir. Sonrasında, eğer bu davranışı yüzünden terapist kendisini görmek istemezse bunu anlayışla karşılayacağını, hatta eğer terapisti süpervizörlerinin sıkıntı çıkaracağını düşünüyorsa, terapiyi kendi isteğiyle bıraktığını ifade edebileceğini ağlayarak belirtmiştir. Danışanın bu tepkisi söz dinleyen teslimci mod ve terk edilmiş çocuk modu şeklinde kavramsallaştırılmış ve tüm bu örüntüdeki olumsuz davranışlara yönelik modlar (danışanın tüm kendiliği değil, modlarla kavramsallaştırılan parçaları) etiketlenmiş ve bu tarz yıkıcı davranışlar seans içerisinde kaçınılmaz bir şekilde yeniden meydana geldiğinde tartışılmak üzere etiketlenmiştir. Bu bozulma aynı zamanda, danışanın çocukluk anılarıyla ilişkilendirilmiş ve annesi gibi herkesin kendisini eleştireceği beklentisi içerisinde olmasıyla sürekli tedbir ve telafi davranışları içerisine girmesi çerçevesinde ele alınmıştır. Sonuç olarak, danışanın, görünen davranışının altında yatan ve şema başa çıkma tepkileri tarafından bastırılan temel ihtiyaçların ele alınması hedeflenmiştir.

Şema terapinin bütünleşik yaklaşımıyla, Bayan B. telafi ve teslim mekanizmasının yıkıcı yönlerini terapötik ilişki içerisinde terapistin aktif rehberliğinde deneyimlemiştir. Kırılgan düşünce ve duyguların şema telafisi ekseninde bastırılması süreç içerisinde azalmış ve Bayan B'nin duygularını şema teslimine girmeden daha açık ifade edebildiği ve işleri kendi başına yürütebildiği deneyimler oluşmaya başlamıştır. Boşanmaya karar vermiş ve ailesine bu süreçte sınır çizebilmiştir. Bu başarılı girişimler Bayan B.'nin özgüvenini arttırmış gözükmektedir ve onu özerklik kazanması için cesaretlendirmektedir.

Bağımlı danışanlarla çalışırken, sonlandırma aşaması da çoğunlukla engel teşkil etmektedir. Bu danışanlar terapiyi güvenli yer olarak algıladıklarından, terapist ile aralarındaki ilişkiyi kaybetme korkusuna kolayca kapılabilirler. Bu yüzden sonlandırma aşaması seansların sıklığı yavaş yavaş azaltılarak düzenlenmelidir (Beck, Freeman ve Davis, 2003; Overholser, 1997). Buna ek olarak Şema terapinin C grubu kişilik bozukluklarıyla etkililiği henüz çalışılmamıştır ve bir araştırma konusu olarak geçerliliğini sürdürmektedir (Vreeswijk, Broersen ve Spinhoven, 2012). Öte yandan, Hoffard ve arkadaşlarının (2005) bir çalışmasında C grubu kişilik bozukluğu olan hastalarla terapist arasındaki ilişki şema terapi kapsamında incelenmiştir. 
Buna göre, hasta ve terapist arasındaki güçlü ittifak, şema devamının ve bir sonraki seansa kadar belirtilerin azalmasıyla sonuçlanmış, ancak bu azalma uzun erimde sürdürülememiştir. Bütün bu unsurlar göz önünde bulundurularak, Bayan B.'nin terapisinde bir yandan yavaş yavaş sonlandırma konusundaki düşünceleri ele alınırken, bir yandan da terapi süreci şema terapinin kendini düzenleme, hedef belirleme, korkulan durumlara yönelik yüzleştirme ve yeni davranışların pekiştirilmesi gibi davranışsal örüntü kırma tekniklerinin uygulandığı uzun erimli bir sonlanma sürecine girilmiştir. Bu çerçevede edinilen kazanımların devamının sağlanması ile ayrılma kaygısı ve bireyselleşmeyle ilişkili ortaya çıkabilecek olası pürüzlerin ele alınması hedeflenmiştir.

\section{Sonuç}

Mevcut vaka analizi BKÖ’nün şema odaklı bilişsel terapi ile tedavisinde terapötik ilişkide karşılaşılabilecek olası sıkıntılara yönelik bilgi vermektedir. Yanı sıra, şemaların gelişimine ve devamına neden olabilecek bağımlılığın farklı yönleri, ebeveynlik stilleri, aile söylemleri ve mevcut ilişkiler bağlamında tartışılmıştır. Araştırmalara göre, bağımlılı̆̆ın gelişimi duyguların bastırıldığı ve özerk davranışın cezalandırıldığı duygusal açıdan soğuk, eleştirel aile ortamında desteklenmektedir. Bu anlamda, bağımlı kişiler ilişkilerinde teslimiyetçi davranmayı öğrenmektedirler. Öte yandan bu kişiler teslimci olarak bilinse de, terk edilme korkularıyla karşı karşıya kaldıklarında daha girişken, hatta istismara kadar varabilecek davranışlar sergileyebilmektedirler.

Böylelikle, bağımlılığın farklı yönlerinin terapötik süreçteki iniş çıkışlarla tanımlanabileceği düşünülmektedir. Bağımlı danışanlarla terapötik ilişki kurmanın kolay olduğu yönündeki genel inancın aksine, BKÖ ile çalışırken de olası engellenmişlik ve çaresizlik duygularının deneyimlenebileceği vurgulanmıştır. Bu yüzden terapistlerin yüzeyde var olan güçlü ittifaka güvenerek altta yatan bağımlı özellikleri atlamamalarının altı çizilmektedir. Yoksa, bastırılmış öfke ve engellenme duyguları terapötik ilişkide pek çok şekilde kendisini gösterebilir. Terapötik ilişki üzerine konuşmak şema terapinin ana araçlarından biri olduğundan, terapist sınırlı yeniden ebeveynliği kullanarak danışanın gereksinimlerini uygun sınırlar içerisinde doyurmalı ve aynı zamanda empatik yüzleştirmeyi de kullanarak danışanın dünyası ve gerçeklik arasında köprü kurabilmelidir. Bu yolla terapist hali hazırda var olan terapi deneyimi üzerine danışanla konuşmaya hazır olmalı, hatta şemalar üzerine konuşabilmek için danışanın mevcut şemalarının seans içinde tetiklenmesini desteklemelidir. Aynı zamanda, danışan tarafından tetiklendiğinde, terapistin kendi şemalarıyla da baş etmeye hazır olması gereklidir.

Sonuç olarak, mevcut vaka analizi BKÖ’nün şema odaklı bilişsel terapi ile tedavisinde ilişkinin rolüne yönelik örnek teşkil etmektedir. Bağımlı kişilik ve terapötik ilişkiye yönelik çalışmaların oldukça nadir olması göz önünde bulundurulduğunda, mevcut çalışmanın bağımlılığa ilişkin farklı varsayım ve fikirlere yönelik klinik veri sağladığı düşünülmektedir. Öte yandan, daha sağlıklı sonuçlara varmak için farklı bütünleşik tekniklerin farklı kültürlerde yürütülen daha geniş ölçekli çalışmalarla test edilmesine ihtiyaç duyulmaktadır. 


\section{Kaynaklar}

Alexander, J. F. ve Abeles, N. (1968). Dependency changes in psychotherapy as related to interpersonal relationships. Journal of consulting and clinical psychology, 32(6), 685.

Arntz, A.(2012). Schema therapy for cluster C personality disorders. The Wiley-Blackwell Handbook of Schema Therapy: Theory, Research, and Practice, 397-414.

Association, A. P. (2000). Diagnostic and statistical manual of mental disorders: DSM-IV-TR ${ }^{\circ}$ : American Psychiatric Pub.

Baillargeon, P., Coté, R. ve Douville, L. (2012). Resolution Process of Therapeutic Alliance Ruptures: A Review of the Literature. Psychology, 3(12), 1049-1058.

Beck, A. T., Freeman, A., ve Davis, D. D. (2007). Cognitive therapy of personality disorders: Guilford Press.

Bender, D. S. (2005). The therapeutic alliance in the treatment of personality disorders. Journal of Psychiatric Practice ${ }^{\circledR}, 11(2), 73-87$.

Bordin, E. S. (1979). The generalizability of the psychoanalytic concept of the working alliance. Psychotherapy: Theory, Research \& Practice, 16(3), 252.

Bornstein, R. F. (1992). The dependent personality: Developmental, social, and clinical perspectives. Psychological Bulletin, 112(1), 3.

Bornstein, R. F. (1993). The dependent personality: Guilford Press.

Bornstein, R. F. (2004). Integrating cognitive and existential treatment strategies in psychotherapy with dependent patients. Journal of Contemporary Psychotherapy, 34(4), 293-309.

Bornstein, R. F. (2011). An interactionist perspective on interpersonal dependency. Current Directions in Psychological Science, 20(2), 124-128.

Bornstein, R. F. (2012). Illuminating a Neglected Clinical Issue: Societal Costs of Interpersonal Dependency and Dependent Personality Disorder. Journal of clinical psychology, 68(7), 766-781. Bornstein, R. F. ve Bowen, R. F. (1995). Dependency in psychotherapy: Toward an integrated treatment approach. Psychotherapy: Theory, Research, Practice, Training, 32(4), 520.

Diener, M. J. ve Monroe, J. M. (2011). The relationship between adult attachment style and therapeutic alliance in individual psychotherapy: A meta-analytic review. Psychotherapy, 48(3), 237.

Faith, C. (2009). Dependent Personality Disorder: A Review of Etiology and Treatment. Graduate Journal of Counseling Psychology, 1(2), 7.

Hoffart, A., Sexton, H. , Nordahl , H.M. and Stiles , T.C. ( 2005 ) Connection between patient and therapist and therapist' s competence in schema - focused therapy of personality problems. Clinical Psychology and Psychotherapy, 3 , 249 - 258

Lingiardi, V., Filippucci, L., ve Baiocco, R. (2005). Therapeutic alliance evaluation in personality disorders psychotherapy. Psychotherapy research, 15(1-2), 45-53.

Mitchell, J. L. (2008). The Relationship Between Interpersonal Dependency and Therapeutic Alliance: Perspectives of Clients and Therapists: ProQuest.

Martin, D. J., Garske, J. P. ve Davis, M. K. (2000). Relation of the therapeutic alliance with outcome and other variables: a meta-analytic review. Journal of consulting and clinical psychology, 68(3), 438.

Matusiewicz, A. K., Hopwood, C. J., Banducci, A. N. ve Lejuez, C. (2010). The effectiveness of cognitive behavioral therapy for personality disorders. The Psychiatric clinics of North America, 33(3), 657.

Overholser, J. C. (1997). Treatment of excessive interpersonal dependency: A cognitive-behavioral model. Journal of Contemporary Psychotherapy, 27(4), 283-301. 
Rafaeli , E. , Bernstein , D. and Young, J. ( 2011 ) Schema Therapy: Distinctive Features . London :Routledge .

Rector, N. A., Zuroff, D. C. ve Segal, Z. V. (1999). Cognitive change and the therapeutic alliance: The role of technical and nontechnical factors in cognitive therapy. Psychotherapy: Theory, Research, Practice, Training, 36(4), 320.

Safran, J. D. ve Muran, J. C. (2006). Has the concept of the therapeutic alliance outlived its usefulness? Psychotherapy: Theory, Research, Practice, Training, 43(3), 286-291.

Soenens, B. (2007) "I will love you if you do as I say": How psychologically controlling parenting undermines parent-child acceptance. ISIPAR Newsletter, 1(3), 1-3.

Soygüt, G. (1999). Bilişsel psikoterapide kişlilerarası süreçler: Terapötik ittifak ve terapötik ittifakta bozulma olguları. Türk Psikoloji Yazıları, 2(4), 1-14.

Soygüt, G. (2004). Bir düzeltici bağlanma ilişkisi olarak psikoterapi: Psikoterapi süreçlerinde Bağlanma ve terapötik ittifak. Türk Psikoloji Yazıları, 7(13), 63-77.

Sperry, L. (2003). Handbook of diagnosis and treatment of the DSM-IV-TR personality disorders: Routledge.

Strauss, J. L., Hayes, A. M., Johnson, S. L., Newman, C. F., Brown, G. K., Barber, J. P., . . Beck, A. T. (2006). Early alliance, alliance ruptures, and symptom change in a nonrandomized trial of cognitive therapy for avoidant and obsessive-compulsive personality disorders. Journal of consulting and clinical psychology, 74(2), 337- 345.

Vane, J. D. (2002). Countertransferential reactions of therapists as a function of dependency and self-criticism: a schema-theory perspective. University of Texas at Austin.

Vreeswijk, van M., Broersen J., Bloo J., ve Haeyen, S (2012). Techniques within schema therapy. The Wiley-Blackwell Handbook of Schema Therapy: Theory, Research, and Practice, 283-299

Vreeswijk, van M., Broersen J. ve Spinhove, P. (2012). The impact of measuring: Therapy results and therapeutic alliance. The Wiley-Blackwell Handbook of Schema Therapy: Theory, Research, and Practice, 283-299.

Young, J. E. (1994). Cognitive therapy for personality disorders: A schema-focused approach (revised): Professional Resource Press/Professional Resource Exchange.

Young, J. E., Klosko, J. S. ve Weishaar, M. E. (2003). Schema therapy: A practitioner's guide: Guilford Press. 


\section{Summary \\ Dependent Personality Pattern and Therapeutic Alliance: An Illustration of Schema-Based Cognitive Therapy}

Dependent personality pattern (DPP) is common when compared to other personality disorders among outpatient population. Dependent people are characterized with strong reliance on others, feelings of defectiveness, impaired autonomy and clingy behaviors. They may involve compliant behaviors in order to maintain emotional nurturance. As can be expected, these features plays crucial role in therapeutic relationship. Since dependent patient's view of self is based on their faulty assumptions of inadequacy, they tend to catastrophize even ordinary withdrawal behaviors of therapists such as vacations or lateness. Therefore, dependent people can display more assertive and destructive behaviors when they perceive their major relationships in danger.

From the perspective of personality disorders, cluster $\mathrm{C}$ group responds better to psychotherapy. Similarly, among cluster $\mathrm{C}$ disorders, patients with dependent personality disorder reveal better treatment outcomes. However, research regarding the effectiveness of different treatment approaches is limited.

In this regard, exploring specific techniques that are especially important for the treatment of the patients with DPP becomes more of an issue. DPP has complicated features and recent research that constantly emphasize the importance of therapeutic relationship in change process. Considering these notions, in the present study, schema therapy was employed as an integrated treatment approach that utilizes the negotiation of therapeutic alliance as a technique. Hence, as a major aim of the therapeutic process, Schema model of dependent personality is utilized with respect to the importance of negotiating therapeutic alliance in terms of schema related cognitions and schema modes.

The current paper aims to investigate specific aspects of dependency and their demonstration in the therapeutic relationship by referring clinical experience and the current literature findings. The literature findings are discussed based on the case of a patient with DPP for a more comprehensive understanding of the issue. Accordingly, the integrative approach of schema therapy combined with the help of the therapeutic experience and the active guidance of the therapist, the patient's destructive ways of overcompensation and surrender coping styles are elicited and repression of the fragile thoughts and emotions in terms of schema overcompensation reduces. These successful attempts seem to increase the patient's self-efficiency and motivation to take more autonomous behaviors. Hence, present study presents a demonstration of how to handle deteriorations in the therapeutic relationship and provides important insights regarding the role of therapeutic relationship in the therapy process of people with DPP.

Keywords: Dependent personality pattern, therapeutic alliance, schema based cognitive therapy 